\title{
$\frac{\sqrt{2}}{5}$
}

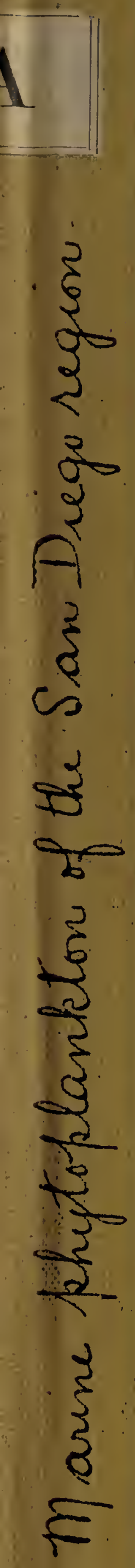

$-2$ 
HARVARD UNIVERSITY.

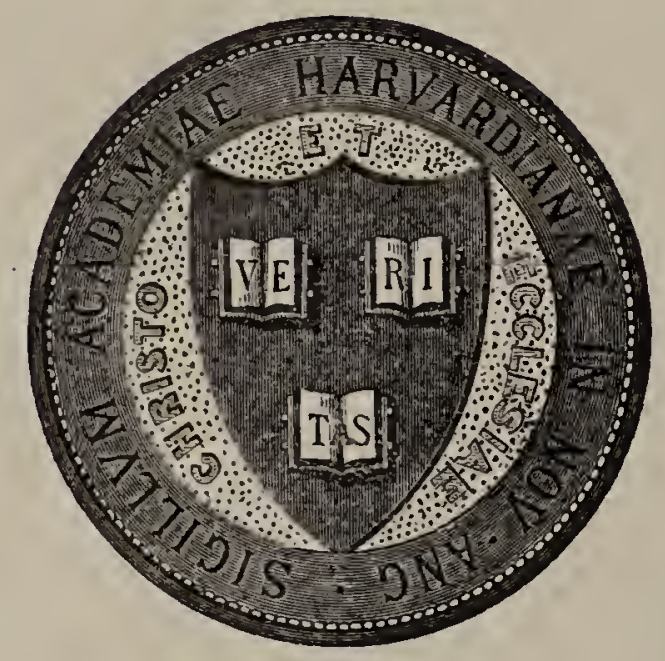

LIBRARY

OF THE

MUSEUM OF COMPARATIVE ZOÖLOGY

$$
60,727
$$

GIFT OF

Harrand college tibrany

famucauy 2,1923 


\section{JAN $2-1923$}

60.727

PRELIMINARY STATISTICAL STUDIES OF MTARINE

PHYTOPLANKTON OF THE SANITDEGGU (IY,

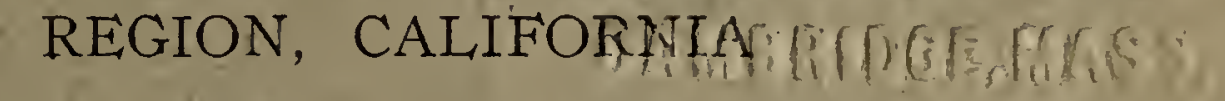

BY

W. E. ALLEN

[Reprinted from SPECIAL PUBLICATIIONS OF BERNICE P.

BISHOP MUSEUM No. 7, pp. 537-554, also 3 insert tables, 192i.] 


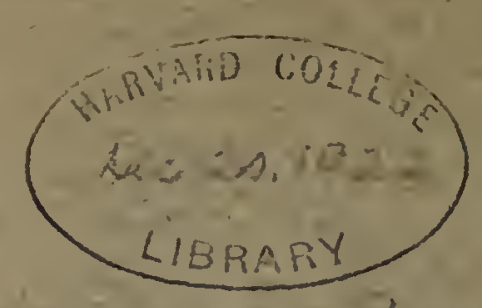

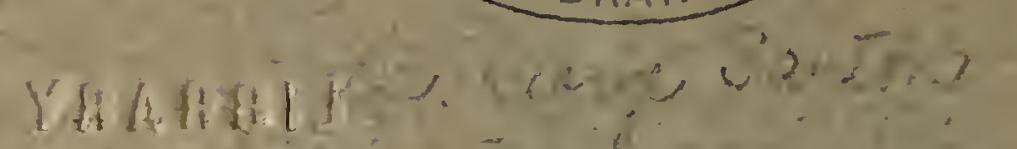

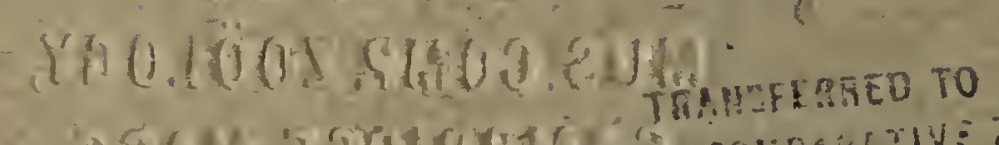

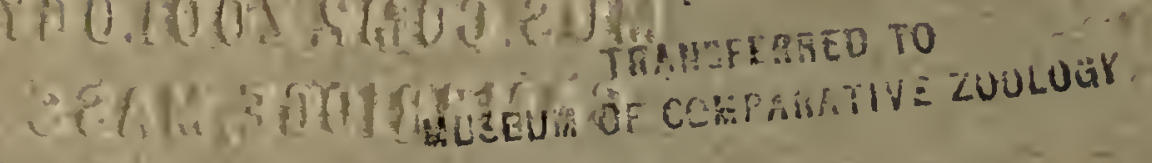


PRELIMINARY STATISTICAL STUDIES OF MARINE PHYTOPLANKTON OF THE SAN DIEGO REGION, CALIFORNIA

\author{
By W. E. AlLeiN
}

INTRODUCTION

Recognizing the basic need of a better understanding of the occurrence and distribution of the synthetic organisms of the sea, the phytoplankton, the Scripps Institution for Biological Research has in the past four years devoted a considerable portion of its resources to increased investigation of these organisms.

The methods of work have been somewhat modified in the last two years along lines of standardization and consistency, but no report on this period is yet available. This paper and the one by Ellis L. Michael which follows discuss the work on phytoplankton of the Southern California region in I9I7 and I9I 8 and are intended to not only give some idea of the preliminary work already done in Pacific waters, but also to offer suggestions for guidance in future operations, either localized or general. These two papers although complete in themselves are based on the same records of numerical distribution and it is therefore desirable to publish them together. The more elementary paper which includes the records essential to both discussions is placed first because that seems to be the natural order.

Much of the work on phytoplankton done in Atlantic waters and in fresh water lakes and rivers shows two desiderata to be especially prominent. First, it is necessary to identify the species present; second, it is essential to maintain, as nearly as possible, continuous observation. It seems appropriate to discuss briefly these desiderata and certain other general features of marine work in phytoplankton before entering upon the explanation of the work done in I9I7 and I9I8.

\title{
DESIDERATA
}

The taxonomy of dinonlagellates of the San Diego region has been well covered by Professor C. A. Kofoid of the University of California. But this region is an infinitesimal portion of the area of the North Pacific and a great deal of strictly taxionomic work remains to be done. Not even an effective beginning has been made on the taxonomy of diatoms of the North Pacific. Fortunately for our work with both types of organ- 
isms, it appears that the more abundant, more prominent, and presumably more important forms are cosmopolitan and fairly easy to recognize. Preliminary statistical work gives little indication that refined tanonomy is of immediate importance, but it ought to be done in preparation for any future time when specific determinations of great accuracy may be needed for interpretation of some series of records.

One of the most, if not the most, urgent need in connection with statistical work with the microplankton is for the establishment of definite stations from which collections may be taken with great frequency and continuity, daily if possible. There ought to be at least one permanent station at which a permanent series may be run to serve as a standard for the work in any given area. With such a standard much effective work can be done by running daily or hourly catches through any one desired or immediately possible period of the year. Of course, it is highly desirable to have such series carried for various depths as well as for the surface but it is quite evident that the field of surface catches has scarcely been touched in most localities and that it still offers ample opportunities for work for many years to come. For practical purposes anything in the uppermost five meters of water may be regarded as belonging to the surface series. One distinct advantage of a standard series of surface catches is that it may serve as the basis of comparison not only of series from other surface areas but from various depths as well. A still greater advantage is in the greater simplicity of procedure and equipment required for surface work. This is of high importance because it vastly increases the probability that the series can be carried continuously. To those who realize the time, work, expense and risk in handling such series it is evident that a break in continuity after one is once established may be a very serious matter, hence anything that will tend to insure its satisfactory maintenance is extremely desirable.

If a good quantitative series is once opened it would be very desirable to have any particular phase of the work handled as nearly as possible by the same individual. Slight changes in individual methods sometimes produce great differences in the final quantitative results.

POSSIBLE, COMMERCIAL APPLICATION

Aside from the academic interest it has in extending our knowledge of the laws of life and in broadening our conception 
of the phenomena of organic existence, I think the study of marine plankton may finally be made to have a decided practical value. The sections following illustrate possibilities.

Naturally, the food relation is the first to attract attention. If a series of records can be secured which will enable us to say that with a certain number of clear days in February and March the seasonal catch of marketable fish may be large because the photosynthetic organisms are able to build up enough food material to supply abundantly the next link in the chain which in turn may supply the next, and so on, up to the fish, it would be worth while even though the information is somewhat indefinite and faulty. Or, if we are able to say that a smaller number of clear days means a poor supply for the markets, or that existent pasturage can support only a limited population, or that certain fishes might be introduced to use it to better advantage, those concerned may be on their guard and not be taken entirely unawares. Some such predictions have been made in connection with fisheries in the North Sea. Judging from present knowledge it is reasonable to hope that if we do our work properly some succeeding generation may be able to make reports to fishermen quite comparable in value to those now made by the weather bureau to farmers. It may be found that some organisms which do not seem to have much value in the food chain, do have a direct value as indices to productivity.

There is another relation which may be as important as the food chain. That is the poison (or at least we may say the exclusion) chain. I mention this because of the considerable evidence to show that certain dinoflagellates may be fatally injurious to fishes and other organisms. If records were available to show the conditions under which such organisms become so numerous as to be of economic importance, advance report of the coming of such conditions might forewarn fishermen and so, to a consiclerable extent, forearm.

\section{SOURCES OF ERROR IN STUDY}

Sources of error have to be considered in connection with any piece of work which pretends to any degree of accuracy. I have taken a good deal of interest in these sources of error and since no considerable number of them is ever mentioned collectively, I have attempted to make a bare list of those most important in such plankton methods as are in general use. Some are important always; some are usually negligible; some counteract 
or cancel other's at times. These conditions are themselves variable and so subject to error of usage and interpretation. For convenience we may call the conditions in which sources of error reside, variants. They may be enumerated as follows:

Variants in sampling.

Selecting the station in the area.

Locating the station in the area.

Drift while hauling Speed

Descencling catch in net.

$$
\text { Direction }
$$

Pitching of boat (especially if vertical haul).

Cross currents.

Ascending catch in vertical hauls.

Pitching of boat.

Clogging of net.

Leakage of net.

Pressure.

Mesh.

Speed of haul.

Cross currents.

Taking from net.

Spillage.

Recording.

Preservation.

Distortion.

Fragmentation.

Examination.

Dilution or concentration.

Transference, spillage and adhesion.

Measuring.

Mixing.

Sampling for count.

Counting.

Fractional sampling of the slicle.

Miscounts $\left\{\begin{array}{l}\text { Small size. } \\ \text { Distortion. } \\ \text { Covered by debris, etc. } \\ \text { Lneven distribution in counting cell. } \\ \text { Personal error, fatigue, etc. } \\ \text { Barl position for identification. } \\ \text { Misnaming. }\end{array}\right.$ 
Recording.

Computing.

Recording.

Interpreting:

Differences in persons.

This looks like a formidable list, and it is. That is one reason why it seems necessary to simplify and to standardize all methods of collecting and handling as much as possible. One unfortunate effect of the contemplation of such a long list of variants is the feeling that any one error will be so much over shadowed by other errors as to be negligible, but it is evident that a minor variant may become very important if carelessly regarded, and that reasonable uniformity of degree of error is more important in a series than is extent of error. A large error clearly recognized may be less injurious than a small one left without consideration.

\section{LENGTH OF PROGRAM}

My experience with these preliminary studies leads me to believe that the most valuable plankton work will be that which is done laboriously over long periods of years. By such work errors or abnormalities of one year or season may be checked by many others so as to give a fair general view of conditions to be expected in a given area. It seems to me that the laws of distribution of life in the sea must be fundamentally the same as those governing life on land and in air. There are areas in the sea with little or no life, and all gradations between this condition and that of great abundance of life. Evidently, many organisms shift, voluntarily or involuntarily, from one area to another. Certainly there are vacillations in productivity corresponding with vacillations in the vast numbers of factors of environment.

These factors of the environment are so numerous that their possible permutations and combinations seem past finding out. The list of chemical factors alone, must be for the sea almost as large as the list of soluble chemical elements and compounds. The list of physical factors, while possibly shorter, is still very long and of primary importance, for example, temperature has a profound influence on the effect of many other factors. Furthermore, the number of biological factors is legion. Surely, with all this complexity, we cannot hope for clear insight until there are enough records to show certain combinations with sufficient frequency to fix our attention. 


\section{MATERIALS AND METHODS}

I consider microplankton particularly useful for the study of these combinations because of the vast numbers of its organisms, their limited motility and their high adaptability through reproduction. Their short life cycles are also a point in favor since the effects of given conditions can be more quickly seen. Large numbers of individuals and large numbers of kinds in a given plankton population are both important in helping to reduce some of the errors in handling and study. Different species, for example, check each other to some extent and so aid in giving proof or in calling attention to error.

These studies were made in the summers of I9I7 and I9IS on miscellaneous and somewhat heterogeneous groups of catches made from time to time and kept in storage. Most of the catches were made in the years I9I7 and I9I8 and some were studied within ten days after being taken.

As described in the detailed discussion the methods of making the catches varied. Methods of counting differed somewhat but most of the counts were made by the Sedgwick-Rafter method. The catch in its preservative formalin was brought to a standard quantity, one cubic centimeter of which was taken after thorongh mixing and placed in a Sedgwick-Rafter slide. The count was then made under the low power of the compound microscope using a Whipple eyepiece micrometer with draw tube so adjusted as to cause the scale to cover one square millimeter in the field of the sixteen millimeter objective. If the catch was large a count was made of fifty fields (covering fifty cubic millimeters of fluid), distributed in groups of five about the margins and middle of the slide. Finally a half slide was examined for less abundant forms which were duly counted. If the catch was light half slicle counts only were made. The counts were afterwards used to compute the total numbers in the catch and the results were tabulated according to taxonomic groups.

Diatoms and dinoflagellates only were counted as the other micro-organisms in the plankton were too few to be of much value for statistical studies. In fact it appears that diatoms are much superior to dinoflagellates for this purpose. Most of the numerically important forms in both groups are usually easy to identify. Some of the less abundant forms are easily confused under conditions of counting and others cannot be identified 
with certainty. In some cases it has been impossible, on account of small size. to distinguish some of those which have numerical importance. Some diatoms have not been specifically identified because too fragmentary or because spore stages were not found. There is no evidence that this deficiency has been sufficiently important to appreciably diminish the value of this statistical work.

\section{MINOR STUDIES}

STONACH CONTENTS OF S.IRDINES AND NNCHOYES

A very limited qualitative study was made of stomach contents of sardines (Sardinella coeruleus Starks and Morris) and anchovies (Engraulis morda.r Girard) which serve as food for the albacore (Thunnus alalunga Gmelin). Five anchovies taken from the stomachs of three albacore were examined on August I3, I9I7. The stomach contents of three of these were wholly unrecognizable. Of the other two, the little which was recognizable consisted of the shells of diatoms and dinoflagellates of various kinds, most of which could not be specifically identified. Three sardines taken at the Institution pier were examined. In two specimens remains of the dinoflagellates Dinophy'sis homunculus Stein and Prorocentrum micans Ehrbg. were found but about ninety-nine per cent of the stomach contents consisted of copepods. In the other sardine the following diatoms and dinoflagellates were found in quantity: Coscinodiscus sp., Chactoceras criophilum Castr. and a number of smaller diatoms; Peridinium divergens Ehrbg., $P$. grandii Ostf., $P$. oceanicum Vauh., and many fragments of shells of Ceratium. This study was not carried further because it was only confirmatory of the well established idea of the important part which diatoms and dinoflagellates play in furnishing food for fishes or their prey.

\section{SOME CASES OF "RED WATER"}

Some isolated qualitative studies of "red water" and similar phenomena were made. These have value in a statistical series because they prove the occurrence of various species of microplankton in enormous swarms and consequently refute the old notion of uniform distribution of small organisms in sea water. Only two of these will be specifically mentioned here. On June 4, I9I7, "red water" was encountered at a point about twelve miles west of San Pedro, where three hauls taken at depths of thirty meters, sub-surface and of surface "scum" 
showed the surface "scum" to be composed of Proroccntrum micans Ehrbg., the sub-surface haul to be composed mainly of this dinoflagellate, and the thirty meter haul to be composed mainly of diatoms and other dinoflagellates. This case of "red water" indicates the probability that plankton swarms are not only definitely limited in surface area occupied but also as to depth.

Another case of "red water" occurred on September II, I9I7, close inshore near Santa Barbara where it was causing a good deal of injury to fish and shore fauna and exciting much inquiry. Captain W. C. Crandall of the Scripps Institution made a special trip to get samples of this swarm. He made a total of twelve surface hauls nearly all of which consisted main!y of Gonyaular polyedra Stein, some almost entirely so.

These two typical cases show not only that plankton swarms occur both inshore and off shore, but that they are to a very large extent exclusive against other organisms in their particular area many of which in fact, are killed.

\section{SOME CASES OF LUMINESCENCE}

In this connection mention may be made of some qualitative catches made by Mr. James Ross along the coast of Lower California in the Spring of I9I9. Early in March a rather rich diatom plankton was found slightly to the north of Magdalena Bay. The Bay itself yielded little in the two catches made. Near Cape Magdalena there was an area of marked luminescence, but little microplankton. The presence of a few Ctenophores in the catch suggests their agency in this phenomenon. In Santa Maria Bay and at Santa Margarita Island catches showed large quantities of Lauderia borealis Gran. Brilliant luminescence was reported there which was also probably due to Ctenophores. In the Gulf of California near Espiritu Santo Island where remarkable luminescence was reported, it again seems probable that Ctenophores were responsible. Near San Martin Island an area of "brown water" was reported which was about fifty miles in extent. Catches from it consisted mainly of Chaetoceras debile $\mathrm{Cl}$. and Nitzschia seriata $\mathrm{Cl}$. Transtitions from luminescent to non-luminescent areas were very sharp. Transition from "brown water" to non-brown was more gradual.

SOME CLOSING NE'T CATCHES AT VARIOUS DEP'THS

On June I4, I9I7, Mr. James Ross and Mr. P. S. Barnhart made a short series of closing net hauls at the kelp beds one 
and one-half miles west of La Jolla Point. These were taken from 5, IO, I 5, 20, 25, and 30 meter depths and one was taken from the 44 meter level to the 30 meter level. They were taken successively as rapidly as possible beginning at Io a. m. This single series showed quite clearly a scant microplankton population in the upper fifteen meters and heavy catches from the 20 meter level to the 44 meter level. Of course, no real conclusions can be reached from a single short series of this sort, but there are some interesting questions suggested by it. Perhaps the most important of these is as to whether large quantities of microplankton frequently occur near the 50 meter level or whether abundance below thirty meters may have been due in this case to mixing by currents induced by proximity to the shore line. There is also the important question as to what factors determine the level at which most microplankton may be found.

\section{SEASONAL SERIES}

We may now consider the "seasonal series" so called because it consists of a series of catches made at nearly weekly intervals at two certain stations, two and five miles off shore respectively from the Scripps Institution. This series ran from December I2, I9I7, to July II, I9I8, covering approximately the most productive plankton season (judged from our other records). It was not possible to make many of these catches at Station 2 (five miles off shore) partly because of rough weather and partly because of lack of time necessary to do the work with the small boat available. For similar reasons some important breaks occurred in the series from Station I (two miles off shore). In spite of these deficiencies the series has a decided interest for comparison with other series and it also gives some valuable indications as to seasonal distribution and ecological successions. The most important points are the showing of a prominent diatom pulse in January characterized especially by Chaetocoras curvisetum $\mathrm{Cl}$. and Ch. conrolutum. Castr., an enormous diatom maximum late in May characterized by Chactoceras criophilum Castr. and Ch. convolutum Castr., a dinoflagellate pulse in December due to Coratiun fusus Ehr. and a dinoflagellate maximum in mid May due to Peridinium crassipes Kof., P. divergens Ehr. and Ceratium furca Ehr.

Next, we may consider the various series of catches made on special collecting cruises of several days duration at different periods in I9I7 and I9I8. These will be discussed in chrono- 
logical order. Methods of making the catches differed somewhat with different cruises but all counts were made by the Sedgwick-Rafter method. Inasmuch as little comparison was made of catches of one series with those of another, the differences in collecting methods are not important for the purpose of the present paper.

PRINCIPAL STUDIES. LATERAL SERIES FIRST SERIES. JULY A (I9I7)

The first series (July A) was made on a run from a point about fifty miles west of San Nicolas Island in to San Pedro on July I4 to 16 inclusive. In this series hauls were made with the fine meshed net (No. 25) from a depth of 200 meters to the surface at eighteen stations selected at more or less regular intervals on the run in. Of the eighteen stations hauled, only six showed large amounts of microplankton. Of the six two were farthest seavard, two near inshore and the other two at about equal distances between. At all of the other stations the catches were light or even scanty. Station I I near San Nicolas Island gave a rather large amount and the catch near Point Fermin was especially large.

Five different diatoms were dominant numerically at one or more stations. Chaetoceras affine (?) Lauder was most abundant at the two stations farthest seaward and at Station I7 just north of Catalina Island. Ch. criophilum Castr. was dominant at all stations from 2 to I 3 inclusive, except Station II. It was much in excess of other diatoms at Stations 7 and 8. Nitzschic seriata $\mathrm{Cl}$. was dominant at Station I4 and $N$. longissima Breb. at Stations 16 and I8, excessively so at the latter. It now becomes necessary to refer to a series of surface catches made from a similar run in June which was not studied in detail. The point of interest is that the June series showed a very marked dominance of Chaetoceras criophilum Castr. or of Nitzschia seriata $\mathrm{Cl}$. at almost all stations in June, while in the present series they are barely able to keep a lead. Smaller Chactoceras forms have replaced $\mathrm{Ch}$. crioplitum to a large extent in most cases. It is also true that Nitsschia longissima Breb. is smaller than $N$. seriata $\mathrm{Cl}$.

The evidence from the July A series points superficially to the view that microplankton is more abundant inshore and near islands. Volumetric studies and statistical analysis of this material made by E. I. Michael show, however, that these differences 
were due to changes from old to new nets on account of loss or tearing. Since we have no accurate indication of the differences in nets no conclusion is possible from this evidence though there is some indication of maximum microplankton production seaward.

SECOND SFRIES. JULY B (I9I 7 )

Another run was made in July which yielded the July B (Table II) series. This run (July 29 and 30) was from a point about fifteen miles west of 'Tanner's Bank to a point about five miles east of San Clemente Island. The twelve catches of this series were made by vertical hauls from a depth of 200 meters. This series consisted of light, or even scanty, catches throughout, and the diatoms were largely fragmented or otherwise in poor condition. They were mostly very small, many were atypical, and species distinction was much more difficult than formerly in the dominant forms.

Dinoflagellates in this series, as was also the case in the July A series, seemed in fair condition though few in numbers.

Since this series did not extend inshore on account of breaking of apparatus, there is no means of comparison of relative abundance inshore and offshore at the time it was taken. It may be noted, however, that this series agrees with July A in showing Nitzschia longissima to be distinctly characteristic of seavard plankton at this season.

The main points suggested by this series are that there is not uniformity of distribution of plankton forms over an area and that there is a still later stage of diatom decline than was shown by the July A series. It is notable also that Dactyliosolen tenuis $\mathrm{Cl}$. was dominant at Station 9 in the midst of an area mainly characterized by Chactoceras contortum Schütt, a fact which shows the possibility of a local break in a widespread dominance.

\section{THIRD SERIES. AUGUST (I9I7)}

One run was made in August and the twenty-eight catches then made constitute the August series. These catches were all made by vertical hauls from depths of 200 meters. This was a long run on zigzag lines from San Diego to Santa Cruz Island. and it extended from August I to August 20 inclusive. On account of its zigzag character, this series cannot well be considered as a whole, hence it may best be broken up into six subseries conveniently lettered A, B, C, D, E, and F. It may as 
well be stated here, however, that this series, as a whole, seems to show about $50 \%$ larger numbers of dinoflagellates than were shown in either July series. It appears that there were less than half as many diatoms as in the July B series and only about onefifth as many as in the July A series. So far as the I9I7 summer records are concerned, then, the general numerical increase of dinoflagellates in midsummer is not marked in this region as it is reported to be in others. The diatom decrease is thus prominent, however. Inasmuch as we know of vast localized increases of dinoflagellates at this time it may be thought that, on the one hand, dinoflagellates are less stable and more localized in distribution than the diatoms, or, on the other hand, that they have an apparent prominence due to the absence of large numbers of diatoms.

This latter view is somewhat supported by the fact that "red water" due to vast numbers of dinoflagellates was reported at various places at about this time. It is also true, however, that more dinoflagellates might escape through the meshes of the net when diatoms are few (because of less clogging) and thus the real increase in numbers would not be shown in the catches. In addition, it is necessary to remember that we do not know as yet the history of the cycles run by these organisms in this region.

Sub-series A, consisting of six catches, covers the line between Point Loma and San Clemente Island, which was omitted in the July B series. It gives some indication of an increase of plankton content inshore, but as the nearest station to the shore was fifteen miles out, the ground of inference is not very certain. The largest numbers of both diatoms and dinoflagellates were caught midway between San Clemente Island and the mainland.

As to the numbers in this sub-series, Chaetoceras affine Laud. was dominant at the two stations nearer San Clemente Island, while a small, unidentified species of Navicula was most numerous toward the mainland. Since this small Navicula seemed to be in fairly good condition it may have been a forerunner of the cycles leading to the autumnal increase in the diatom population.

About the only inference to be derived from this sub-series is that different stations present differences in kinds and relative numbers of organisms. 
Sub-series B, consisting of four catches between San Clemente Island and Oceanside, shows nothing of very great prominence, except that the smallest numbers of both diatoms and dinoflagellates were found at Station 9 nidway between San Clemente Island and Oceanside. Inasmuch as this is almost directly opposite to the condition in sub-series A, it might at first. be thought that the showing was due to leakage of the net or some other accident in hauling of the net at Station 9. Station 8 , however, is also low in numbers, and it may be that there actually was such remarkable scarcity of all diatoms and dinoflagellates at Station 9 as the records show.

Chactoceras affine was dominant at all four of the stations in this sub-series, except in the small catch at Station 9. where Pcridinium crassipes was most numerous.

Sub-series C includes five stations on the line from Oceanside to Santa Catalina Island. It, also, is mainly impressive through the fact that a very low minimum for both diatoms and dinoflagellates occurs at Station i4, midway between the island and the mainland. In this case, however, the maximum for diatoms occurs about six miles nearer Santa Catalina at Station I6, while the maximum for dinoflagellates occurs at Station I6, about eight miles from Catalina. The small Navicula sp. was dominant at three stations, Chactoceras affine at one and Peridinium cerasus at one.

Sub-series D includes three stations between Santa Catalina and San Pedro. It agrees with the July series in showing a marked increase of diatoms nearer San Pedro. This is not yet accounted for in this series. Chaetoceras affine and a small $N a-$ vicula sp. are the numerical dominants at stations I9, I7, and I8.

Sub-series E includes six stations from Pt. Fermin to the vicinity of Santa Barbara Island. As far as it goes this subseries covers a good deal of the same ground covered by the July I9I7 series. For this reason it has more interest than the other sub-series in this group.

Both diatoms and dinoflagellates appeared in largest numbers at Station 26 about six miles southeast of Santa Barbara Island. The numbers at Station 20 near Pt. Fermin were deciderly smaller. This distribution is markedly different from that in the July I9I7 series when the station near Pt. Fermin showed largest numbers of all. As noted in discussing that series this 
showing of the July series was due to the net. Hence the showing of the August series is probably correct.

Nitsschia seriata was numerically dominant at the three stations farthest seavard, occurring in relatively enormous numbers at the two stations nearest Santa Barbara Island. This is approximately the general region in which it was especially prominent in the June series and the July I9I7 series. The small Navicula was most numerous at Station $2 \mathrm{I}$, and Chactocoras affine at Stations 22 and 20.

This sub-series shows plainly that there are marked differences in plankton content in different localities. While it does not support the questionable indication of the July I9I7 series that heavier plankton occurs close inshore, it does show some resemblance to that condition by its heavier plankton being found near Santa Barbara Island. The dominance of Nitsschia scriata in the region near this island at three different times suggests the possibility of an organism being characteristic of a given area over a considerable period of time.

Sub-series $\mathrm{F}$ includes four stations not covered in such a way as to be directly comparable with the other sub-series. Station 40 was just north of Santa Cruz Island. Nitzschia seriata was distinctly dominant here, giving the impression that something in nearness to islands favors it. The catch as a whole closely resembled others in the main series except that dinoflagellates were made prominent by large numbers of Gony'aula.r polyedra.

Stations $50,5 \mathrm{I}$ and 52 were about fifteen or twenty miles from Oceanside. Nothing of prominence appears in their records to indicate much difference from conditions in that region a week before, except that Station 5I is almost identical with Station Io and it shows a dominance of the small Navicula, instead of Chactoceras affine as at the other time.

Considering this August series again as a whole. it is interesting to note that Chactoceras affine is dominant at ten stations out of the twenty-eight, the small Navicula at twelve stations, Nitaschia seriata at four sta.ions. Chactoccras decipiens at one station and Peridinium cerasus at one station.

COLIECTIVE DISCUSSION OF IgIS SERIES IN COMPARISON WITH I9I7 SERIES

The work in I9I8 was along lines somewhat similar to those of I9I7, hence it may be most conveniently discussed by making comparisons. Only two additional points seem to be 
clearly indicated. First, it seems almost certain that the production of diatoms reaches a maximum somewhere from April to early June, a conclusion which agrees with the results of various European observations. Second, owing partly to the use of the shorter, fifty meter vertical haul, a complete series of catches with the No. 25 net was made on the long August trip, even including catches in the Santa Barbara Channel and beyond Point Conception.

Monthly cruises (except April) were made from January to August in 19I8. The January trip shows nothing of particular note unless it be that Chactoceras criophilum Castr. is the most prominent microplankton in nearly the whole lot of rather light catches. February catches were slightly heavier with a predominance of Chactoceras curvisetum Cl. In March Chactoceras curvisetum retained its dominance in much heavier catches. Nitsschia pungens Grum. was most abundant at the two stations east of San Nicolas Island, however. In May N. pungens was much the most prominent microplankton at all stations beyond Santa Barbara Island. Considering the small size of this diatom and the probable heavy losses through the net, this is a remarkable showing in a group of rather heavy catches. N. pungens retained its prominence in June, $N$. seriata being next most abundant. Considering the opinion of some experts that $N$. pungens and $N$. seriata are merely different forms of the same species, this fact has considerable interest. Catches in June ('Table III) were distinctly lighter.

Some details of the August records require more attention than those for other months. For one thing, there is the same relative scarcity of microplankton at the two stations (No. 6 and No. 7) midway between San Clemente and Oceanside, as has already been noted for the August trip of igI7. It is interesting to see that this 1918 cruise also shows a similar scarcity at Station Io midway between San Juan and Santa Catalina Island. As yet there is no means of knowing whether this is the typical condition in those localities, but there is some probability that it is and the question of the possible explanation is interesting. The distance from land is not such as to make it probable that dearth of organic matter is the cause. Other factors must be responsible for the peculiar condition. The most likely explanation seems to be in some peculiarity of the currents.

Another interesting feature of this August trip is its greater extent beyond San Nicolas. As a matter of convenience in tabu- 
lating the records, the stations near and beyond San Nicolas have been arbitrarily grouped together into an "off shore group" by way of contrast to the "south inshore group" between San Diego and Santa Barabara Island and the "north inshore group" north of Santa Cruz Island. This "off shore group" showed large numbers of diatoms to quite a distance beyond San Nicolas, but there was a very marked reduction in numbers at the seven stations farthest out. This recluction was not so marked for the dinoflagellates which kept up their numbers fairly well at the outer stations. The larger number of both diatoms and dinoflagellates in the vicinity of Point Conception is quite noticeable and leads to the question as to whether this indicates a later maximum of microplankton production in that region than we have found farther south. Another feature of this August series is the prominence of Rhizosolenia calcar avis Schultze. At about the same time in I9I7 Nitzschia seriata $\mathrm{Cl}$. was much the most prominent in similar locations. This condition may be due to a difference in seasonal dominants.

From some extra hauls in the August series a comparative study was made of the results of vertical hauling at depths of 200 meters and at the surface in addition to the regular vertical hauls of fifty meters. Too few hauls were taken to be conclusive. In this case the catches were not greatly different except that the surface hauls appeared rather light, and this may have been due to difference in hauling. Vertical hauls of 200 meters and fifty meters were much alike, a fact which indicates that practically all of the microplankton is usually to be found at. less depths than 50 meters.

SUMMARY OF RESULTS OF STUDIES OF LATERAL SERIES OF I9I7 AND I9IS

The summary of the results of these studies requires little space.

I. It is fairly evident that diatoms usually exceed dinoflagellates in numbers and also in bulk. August and September seems to be the only period of the year in which there is extensive exception to this rule. There is some evidence that maxima of dinoflagellates come with minima of diatoms and vice versa.

2. There is strong indication that annual maxima for both diatoms and dinoflagellates occur in the period from April to early June.

3. There is indication that the minimum of diatom production for the year comes. in August or September. 
4. 'There is some evidence that the annual minimum of dinoflagellate production comes sometimes in the winter. It would also appear that dinoflagellates are much more unstable in occurrence than diatoms. These differences may prove of distinct value in interpretation of relative distribution of microplankton in the sea.

5. It is very evident that plankton content differs markedly in different areas at a given time and in a given area at different times, even at short intervals.

6. It is very evident that plankton collections taken at long and irregular intervals of time are of little value for statistical study of the biology of the sea.

7. It is necessary to improve and to standardize the methods of collecting. Some way should be found to locate the organisms more accurately, to make the records more nearly continuous, and to place all phases of the work in the hands of skilled, interested and persevering workers. Otherwise the work will remain at the dead level of repeated preliminary activities for which no advance is provided.

8. The problem of marine plankton distribution is almost identical with the problem of marine life, one of the most difficult problems which the human mind can set for itself. It cannot be completely solved in a day, or a year, or a century. It requires a long series of observations at many definite stations in definite areas, made through frequent collections during decades or centuries of time. Continuity of effort both in time and space is essential to real progress toward solution of plankton problems.

9. The marine plankton problem is, for practical purposes, a problem of ecological cycles, associations and successions. It is distinctly general rather than specific in nature.

Io. There is little hope of commercial utilization of studies of marine microplankton until methods have been made more exact and more nearly standardized, and until trustworthy records have accumulated to such an extent as to compare favorably with the records which are used for tidal and meteorological predictions. Instead of being content with distinguishing biological sciences from "exact sciences", it would be worth while to see how exact they can be made.

\section{LITERATURE USED}

Gran, H. H. Diatomeen. Nordisches Plankton. Botanischer Tiel. Kiel und Leipzig. Igos. 
Jörgensen, E. Die Ceratien. Eine kurze Monographie der Gattung Ceratium Schrank. Internationalen Revue der gesamten Hydrobiologie und Hydrographie. (Band IV) Biologisches Supplement. Zweite Serie. IgI I.

Kofoid, C. E. Dinoflagellates of the San Diego Region IV. The Genus Gonyaulax. Univ. of Calif. Publ. in Zoöl 8. I87-269 pls. 9-I9. I9II.

Okamura, K. Some Littoral Diatoms of Japan. Report of the Imperial Fisheries Institute. Vol. VII No. IV. IgII.

Paulsen, Ove. Peridiniales. Nordisches Plankton. Botanischer Teil. Kiel and Leipzig. I900.

\section{NO'TE ON THE TABLES}

On account of the preliminary character of these studies it has not been considered necessary to print the complete records, hence the tables for July I9I7 and June rgis are the only ones included with this paper.

All catches were made by vertical hauls with the number 25 tow net. Hauls for I9I7 were from depths of 200 meters to the surface. Those for 1918 were from depths of fifty meters to the surface. Numbers given in tables are estimated totals in each catch of any species or designated group. Where two numbers are given the smaller gives the number of colonies.

The map accompanying the paper by $\mathrm{E}$. L. Michael published in the proceedings of this Conference covers most of the territory referred to in this paper. 

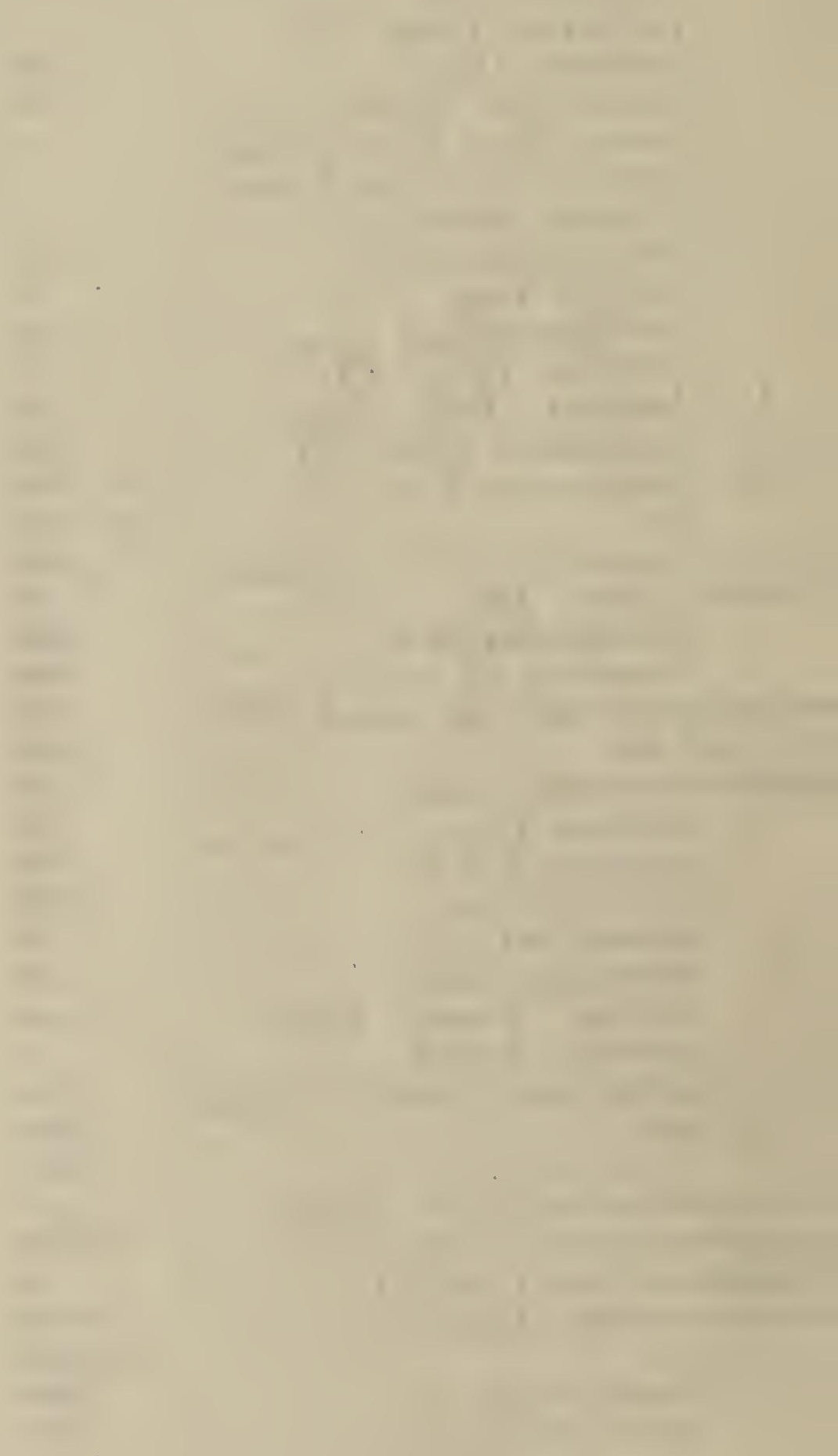

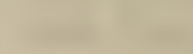


T.ABLE II. PHYTOPLANKTON-FISHERIES SERIES. HAUL NUMBERS F.136-F.18\%. JULY 20-31, 1917

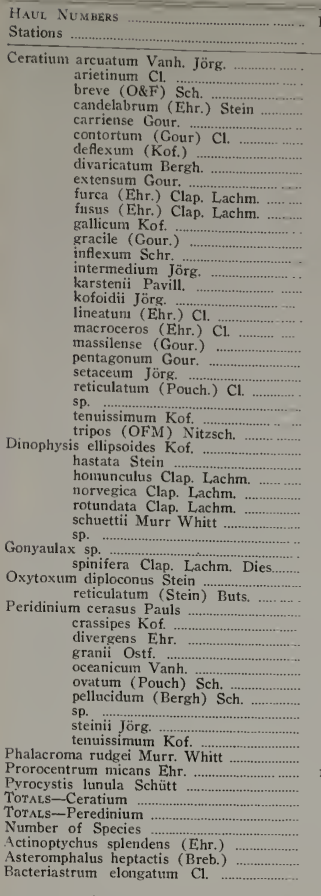

Biddulphia biddulphiana (Smith) Chaetoceros affine Lauder

atlanticum $\mathrm{Cl}$

constrictum $\mathrm{Cr}$....

contortum Schütt

criophilum Castr.

criophilum f. volans (Sch.)

decipiens $\mathrm{Cl}$.

dichaeta Ehr.

furca $\mathrm{Cl}$.

Schr

pelagicum $\mathrm{Cl}$.

peruvianum Btw.

teres $\mathrm{Cl}$.

Corethron criophilum Cast.

Coscinodiscus radiatus Ehr

Dactyliosolen tenuis $\mathrm{Cl}$.

Diatoma sp.

Eucampia groenlandica

Hemiaulus hauckii Grun.

Navicula sp.

Vitzschia longissima (Breb.)

Planktoniella sol (Wallich)

Rhizosolenia alat Btw.

$$
\text { farocensis Otsenf. }
$$

fragillima Bergon.

hebetata (Bail)
obtusa Hensen

robusta Norm.

styliformis Btw.

Thalassiosira subtilis (Ostenf.)

Thalassiotlirix acuta Karsten

longissima Cl. \& Grun.

Toral,s-Chaetoceros

Torals-Diatoms

Number of Species

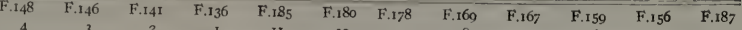

$\begin{array}{cccccccccccc}4 & 3 & 2 & 1 & \text { II } & \text { I0 } & 9 & 8 & 7 & 6 & 5 & 12\end{array}$

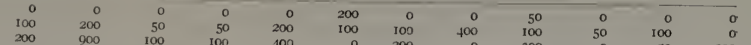

$\begin{array}{llll}0 & 100 \\ 0 & 0 & 0 & 0\end{array}$
$\begin{array}{rrr}0 & 0 \\ 200 & 1.000 & 200\end{array}$ $\begin{array}{rrr}100 & 100 \\ 0 & 200 & 0\end{array}$ 100

0
100

200
$100 \quad 300$

100
200

100
0
0

$\begin{array}{rrr}400 & 500 & 0 \\ 0 & 0 & 0 \\ 0 & 0 & 350\end{array}$

100

(1)

$\begin{array}{lll}0 & 0 & 0 \\ 0 & 0 & 0 \\ 0 & 50 & 0\end{array}$

0
1,300
1,30

$\begin{array}{rr}0 & 0 \\ 2,400 & 750\end{array}$

50
350

0
0
900
600

$\begin{array}{rrr}1,700 & 2,400 & 750 \\ 1,000 & 5.800 & 1,100 \\ 1,100 & 600 & 300\end{array}$

350
950
100
50

300
0
600

600
$r, 100$ 50

$\begin{array}{rrrr}50 & 0 & 0 & 0 \\ 50 & 100 & 100 & 100\end{array}$

$200 \quad 100$

$200 \quad 500$

$\begin{array}{rr}200 & 800 \\ 200 & 300\end{array}$

$\begin{array}{rr}200 & 100 \\ 0 & 0\end{array}$

$100 \quad 100$

$\begin{array}{rrrr}100 & 100 & 0 & 100 \\ 0 & 100 & 0 & 200 \\ 3,300 & 3 ., 900 & 3.600 & 2,800 \\ 2,900 & 2,200 & 4,500 & 2,050\end{array}$

$\begin{array}{rrrr}22 & 21 & 26 & 2,050 \\ .0 & 100 & 100 & 53 \\ & 20 & 400 & 500\end{array}$

$\begin{array}{rrrr}2,000 & 200 & 100 & 50 \\ & 400 & 500 \\ 4.000 & 5.000 & 1.000\end{array}$

2,000 1,000

$\begin{array}{rrrr}0 & 0 & 0 & 2,000\end{array}$

$\begin{array}{rrrr}3,000 & 3.500 & 2,000 & 3,000 \\ 4.000 & 13.500 & 8,000 & 30,000\end{array}$

$\begin{array}{rrrr}3,000 & 4,500 & 9,000 & 200 \\ 11,000 & 15,000\end{array}$

15,000
56,000

1,500
1,500

$\begin{array}{rrr}0 & 0 & 9,500 \\ 12,000 & 3,000 & 1,500 \\ 14,500 & 9,500\end{array}$

16,000
87,000

16,000
87,000
2,000

2,000
6,000
2,000

10,000
4,000

4,000
15,000

$\begin{array}{rr}4,000 & 5.000 \\ 0 . \quad 18,000 & 18,000\end{array}$

$0.000 \quad 4.000$
0.000

$\begin{array}{rrr}0 & 0 & 0 \\ 4,000 & 6,000 & 5.000\end{array}$

$\begin{array}{rrr}10,000 & 21,000 & 28,000 \\ 0 & 28,000\end{array}$

$800 \quad 0 \quad 0 \quad 1,000$

$\begin{array}{rrrr}17,000 & 6,000 & 25,000 & 13,000\end{array}$

$\begin{array}{rrr}9,000 & 31,000 & 195,000 \\ 2,000 & 2,000\end{array}$

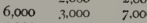

$\begin{array}{rrr}4,000 & 0 & 7.000 \\ 6,000 & 5.000 & 3.000 \\ 28,000 & 17.000\end{array}$

$\begin{array}{rr}6,000 & 28,000 \\ 3,000 & 3,000\end{array}$

$\quad 3.500$

3.500
16.500

6.500
2,000
5.500

$\begin{array}{llll}3,000 & 5.500 & 5,000\end{array}$

1,000
1,000

$\begin{array}{rrrr}0 & 1,000 & 0 & 0 \\ 0 & 0 & 0 & 1,500 \\ 0 & 3,000 & 4000 & 5.500\end{array}$

$\begin{array}{rrrrr}0 & 3.000 & 4,000 & 5,500 & 1,500 \\ & 6,000 & 4,000 & 8,500 & 1,500\end{array}$

$\begin{array}{rrrr}3,000 & 13,000 & 13,000 & 21,000 \\ 2,000 & 1,050 & 0 & 3,000\end{array}$

$\begin{array}{rr}1,000 & 5,000 \\ 5,000 & 5,000\end{array}$

$\begin{array}{rr}5,000 & 5,000 \\ 12,000 & 13,000\end{array}$

$\begin{array}{ll}16,000 & 1,3,000 \\ 35,000 & 3,000\end{array}$

$\begin{array}{rrr}5.500 & 3.500 \quad 21,000\end{array}$

$\begin{array}{rr}34,000 & 38,000 \\ 0 & 4,000\end{array}$

$4,000 \quad 2,000 \quad 2,000$

$\begin{array}{rrrr}100 & 200 & 2,000 & 3,000\end{array}$

$\begin{array}{rrrr}700 & 300 & 5.000 & 2.000\end{array}$

$\begin{array}{rrrr}4,000 & 10,000 & 8,000 & 7,000 \\ 15,000 & 49,000 & 34,000 & 10,000\end{array}$

10,000
1,000

$\begin{array}{rr}10,000 & 1,000 \\ 10 & 1,500\end{array}$

$\mathrm{I}, 000$

:

$\begin{array}{rrr}0 & 0 & 0 \\ 2,000 & 3.000 & 1,000\end{array}$

$\begin{array}{rrr}2,000 & 3,000 & 1,000 \\ 5,000 & 5,000 & 5,000 \\ 6,000 & 11,000 & 5,000\end{array}$

$\begin{array}{rrrr}6,000 & 11,000 & 5,000 & 5,500\end{array}$

$\begin{array}{llll}3.000 & 13,000 & 20,000 & 3.500\end{array}$

$\begin{array}{rrrr}6,000 & .36,000 & 68.000 & 31,000\end{array}$

$\begin{array}{rrrrr}1,000 & 800 & 1.000 & 600 & 7,500 \\ 2,000 & 0 & 100 & 2,000 & 4,500\end{array}$

$\begin{array}{rrrrr}0 & 0 & 0 & 0 & 0 \\ 0 & 0 & 300 & 0 & 0\end{array}$

$\begin{array}{rrrrr}5.000 & 3,000 & 2,000 & 7,000 & 5.500\end{array}$

$\begin{array}{rrrrr}4,000 & 1,000 & 2,000 & 2,000 & 3.500 \\ 0 & 0 & 0 & 0 & 0 \\ 1,000 & 100 & 2,000 & 100 & 1.000\end{array}$

$\begin{array}{rrrrr}1,000 & 100 & 2,000 & 100 & 1,000 \\ 2,000 & 5,000 & 1,000 & 3,000 & 1,000\end{array}$

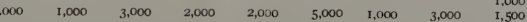

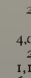

4,000 200
1,100
56,000
149,500
856,700

$\begin{array}{rrrrrr}0 & 0 & 0 & 0 & 0 & 0 \\ 5,000 & 2,000 & 11,000 & 0 & 0 & 0 \\ 2,000 & 2,000 & 3,000 & 12,000 & 4,500 & 3,500\end{array}$

$\begin{array}{rrrrr} & 2,000 & 3,000 & 12,000 & 4,500 \\ 0 & 0 & 5,000 & 7,000 & 1,000 \\ 7,000 & 22,000 & 2,500\end{array}$

$\begin{array}{rrrr}0 & 9,000 & 22,000 & 2,500 \\ 42,000 & 48,000 & 77,000 & 54,000\end{array}$ $\begin{array}{rrrr}177,800 & 169,000 & 416,000 & 222,000 \\ 236,500 & 351,200 & 633,300 & 319,100\end{array}$ 

TABLE, III. PHYTOPLANKTON-FISHERIES SERIES. HAUL NUMBERS F. 553-F.606. JUNE 27-29, I918

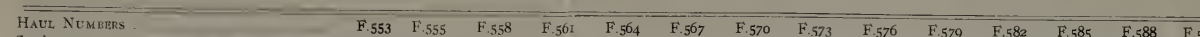

Stations

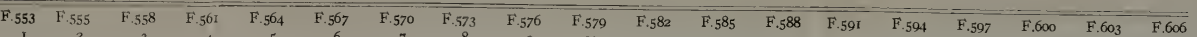

Actinoptychus undulatus (Bail.)
Asteromphalus heptactis (Breb.)

Asteromplalus heptactis (Breb.)
Bacteriastrum elongatum $\mathrm{Cl}$.

varians Lauder .....

$\begin{array}{rrr}0 & 0 & 0 \\ 0 & 2,0000 & 0 \\ 2,000 & 12,000 \\ 8,000 & 2,000 & 28,000 \\ 2,000 & 2,000 & 400 \\ 4,000 & 4,000 & 2,800 \\ 200 & 2000 & \\ 200 & 200 & 0\end{array}$

punctata (Grev)
mobiliensis (Bail.)
Chaetoceros A

breve Schitt .....................

$\begin{array}{rrr}200 & 0 & 0 \\ 400 & 200 & 0 \\ 0 & 0 & 4.000 \\ 0 & 16,000 \\ 0 & 200 & \end{array}$

constrictum Gran.
contortum Schitt

convolutum Castr.

\begin{tabular}{rr}
$-\quad 2,000$ & 0 \\
\hline &, 000 \\
\hline & 4,000
\end{tabular}

criophilum Castr....-
criophilum $\mathrm{f}$. volans (Sch.)

curvisetum Cleve
decipiens $\mathrm{Cl}$. ....
densum Cleve

diadema (Ehr.)

dichaeta Ehr.

didymum Ehr.

difficile Cleve

furca $\mathrm{Cl}$.
pelagicum $\mathrm{Cl}$.

pendulum Kars.
peruvianum Btw.

peruvianum Btw.
pseudocrinitum Osten
scolopendra (Cleve)

200
600

$\begin{array}{rrr}0 & 14,000 & 4,000 \\ 4,000 & 4,000 & 44,000 \\ 2,0,000 & 4,000 \\ 22,000 & 1,000 \\ 2,000 & 2,000 & 8,000 \\ 2,000 & 6000 & 12000\end{array}$

$\begin{array}{rrr}2,0000 & 2,000 & 8,000 \\ 2,000 & 6,000 & 12,000 \\ 0 & 6,000 & 0 \\ 2,000 & & 0 \\ 6,000 & 0 & 0\end{array}$

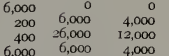

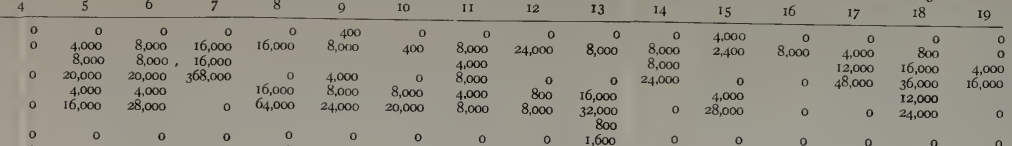

\begin{tabular}{rrr}
6,000 & 6,000 & 4,000 \\
1,000 & 22,000 & 4,000 \\
\hline
\end{tabular}

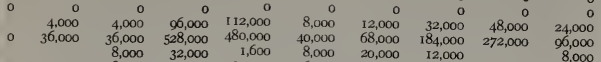

$\begin{array}{rrr} & 2,000 \\ 0 & 4,000 \\ 4 & 4000 \\ 0 & 16,000 \\ 0 & 0 & 0 \\ 0\end{array}$

200

$\begin{array}{rrr}2,000 & 4,000 \\ 0 . & 4,000 \\ 0.000 & 12,000 \\ 0.000 & 4,000\end{array}$

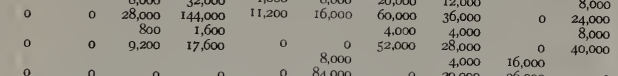

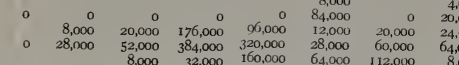

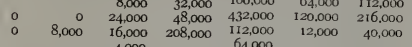

16,000
96,000
8,000

$\begin{array}{rrrrr}0 & 0 & 24,000 & 48,000 & 432,000 \\ 0 & 8,000 & 11,0,000 & 208,000 & 64,000 \\ 0 & 0 & 4,000 & 64,000 \\ 0 & 8,000 & 0 & 304,000\end{array}$

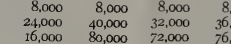

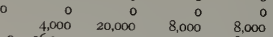

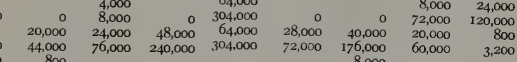

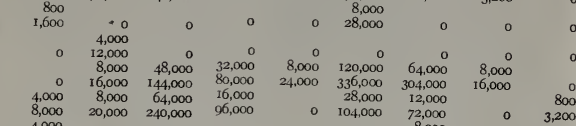

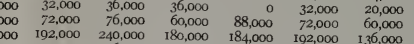

$\begin{array}{rrrr}0 & 0 & 12,000 \\ 0 & 0 & 116,000 \\ 116\end{array}$

\begin{tabular}{ccc}
10,000 & 8,000 & 616,0000 \\
10,000 & 24,000 & 76,000 \\
\hline
\end{tabular}

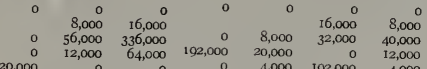

$\begin{array}{rrrrrrr}20,000 & 0 & 4,0 & 0 & 4,000 & 192,000 & 4,000 \\ 0 & 0 & 0 & 0 & 4,000 \\ 16,000 & 0 & 0 \\ 4,000 & 4,000 & 3,200 & 112,000 & & 8,000 & 28,000\end{array}$

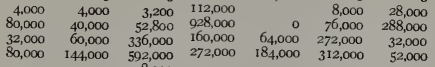

$\begin{array}{rrrr}8,000 & 24,000 & 16,000 & 4,000 \\ 0 & 0 & 16,0,00 & 12,000 \\ 0 & 0 & 8,000 & 4,000 \\ 0 & 32,000 & 1,800\end{array}$

$\begin{array}{rrrrrrr}32,000 & 16,000 & 0 & 0 & 0 & 0 & 0 \\ 0 & 800 & 8,000 & 0 & 20,000 & 20,000 & 20,000\end{array}$

teres $\mathrm{Cl}$

$\begin{array}{ccc}0 & 0 & 0 \\ \circ & 0 & 40,000 \\ 20,000\end{array}$

Corethron valdiviae Karsten
Coscinodiscus granii Gough

Coscinodiscus granii Gou
radiatus Fish

Ditylium $s$

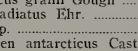

Finpodiscus argus (Ehr.)

Fragilaria

marima (Lyng.)

Lithodesmium undulatum Ehr.

Navicula sp. ........
Nitzschia longissima (Breb.)

pelagica
pungens (Grun.)

seriata $\mathrm{Cl}$.

Planktoniella sol (Wallich)
Pleurosigma elongatum W. Sm.

Pleurosigma elongatum W. Sm.
Rhizosolenia alata Btw.
calcar avis Schuetz.

calcar avis Sching
cylindrus (C1)
hebetata (Bail)

obtusa Hensen
robusta Norm.

stolterfothii Pera

styliformis Btw.
Stephanopyxis palmeriana (Grun.)

$\begin{array}{rrr}0 & 400 & 800 \\ 0 & 2,00 \\ 0 & 400 \\ 0 & 8,000 & 2,000 \\ 2,000 & 8,000 \\ 2,000 & 0 & 400 \\ 4,000 & 0 & 4,000 \\ 16,000\end{array}$

8,000
36,000
300

$\begin{array}{rrrrrrr}48,000 & 72,000 & 40,000 & 36,000 & 32,000 & 72,000 & 66,0,000 \\ 56,000 & 120,000 & 92,000 & 52,000 & 88,000 & 176,000 & 100,000\end{array}$

Thalassiosira condensata Cleve

subtilis (Ostenf.)

acuta Karsten ..........
frauenfeldii (Grun.)

longissima $\mathrm{Cl}$. \& Grun

ToraLS-Diatoms

No. of Species

Ceratium arietinum $\mathrm{Cl}$

belone (Cl.)
breve (Ostenf et Schm.) Sch.

extensum Gour,
furca (Ehr.) Clap. Lachm.

fusus (Ehr.) Clap. Lachm...

inclinatum (Kof.)
intermedium Jörg

intermedium
kofoidii Jörg. $^{2}$.

lamellicorne Kof.
longipes Bailey

longipes Bailey ..........
macroceros (Ehr.) $\mathrm{Cl}$
massiliense (Gour)

massiliense (Gour)
molle

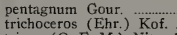

tripos (O. F. M.) Nitzsch

tripos (O. F. M.) Nitzsch
Dinophysis acuminata Clap. Lachm
homunculus Stein

rotundata Clap. Lachm

schütii Murr. u.
Gonyaulax polyedra Stein
polygramma Ste

polygramma Stein
spinifera Clap. Lachm. Dies

Gymnodinium lohmanni Paul
Peridinum

crassipes Kof
depressum Bail

depressum Bail.
divergens Ehr.

granii Ostf. .........

pellucidum (Bergh.) Schütt

pentagonum Gra.

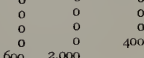

$\circ$

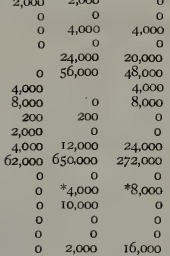

0
0
0
0

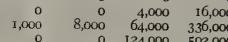

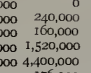

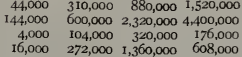

$\begin{array}{rr}0 & \\ 0 & 28,000 \\ 8,000 & 603,\end{array}$

$\begin{array}{rrrr}1,22,000 & 32,000 & 48,000 & 0 \\ 76,000 & 30,000 & 144,000 & 28,000\end{array}$

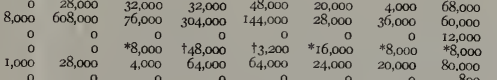

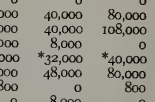

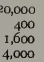

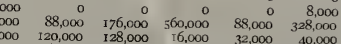

$\begin{array}{rrrr}12,000 & 16,000 & 0 & 1,600 \\ 0 & 0 & 16,000\end{array}$

steinii Jörg.
sta rudgei Murr. Whitt.

Phalacroma rudgei Murr.
Poddampas palmipes Stein
Prorocentrum micans Ehr.

Pyrocystis lunula Schüt

Triposolenia bicornis Ko
TorALS-Dinoflagellatcs
Tof Sing

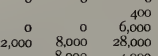

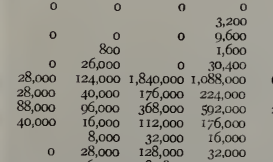

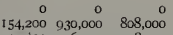
$\begin{array}{rrr}154,200 & 930,000 & 808,000 \\ 24,4,00 & 36,200 & 108,000 \\ 5,5,000 & 137,000 & 324,400 \\ 2 & 0 & 32,40\end{array}$
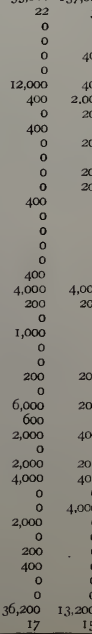

30
400

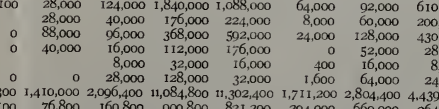

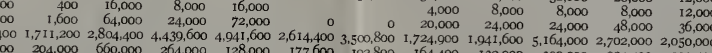
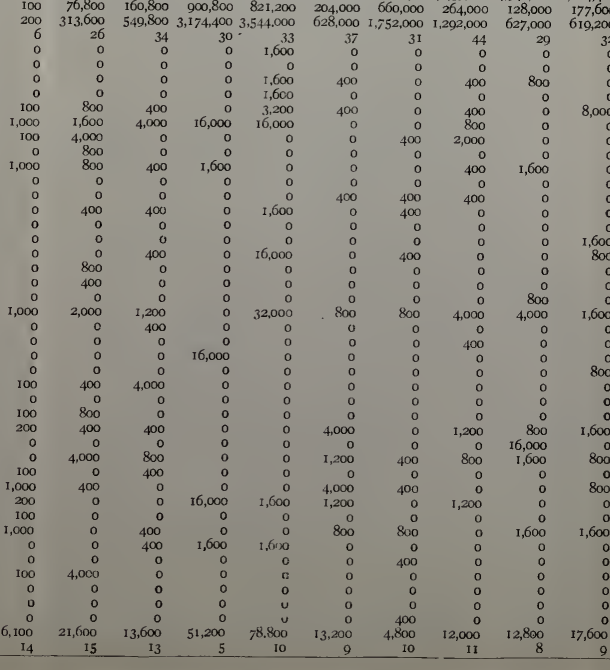

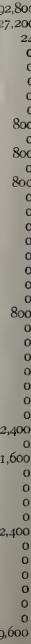

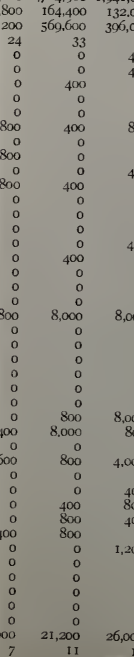

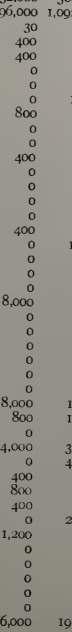

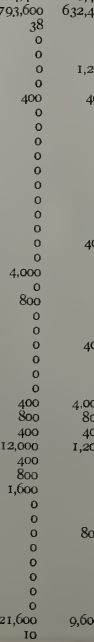









\section{Photomount Pamphlet Binder}

Gaylord Bros. Makers

Syracuse, $N$. Y. PAT. JAN 21, 1908
MCZ ERNST MAYR LIBRARY

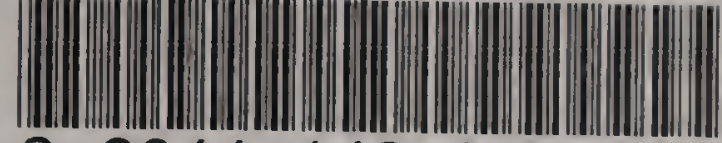

$\begin{array}{lllll}3 & 2044 & 143 & 977 & 270\end{array}$ 


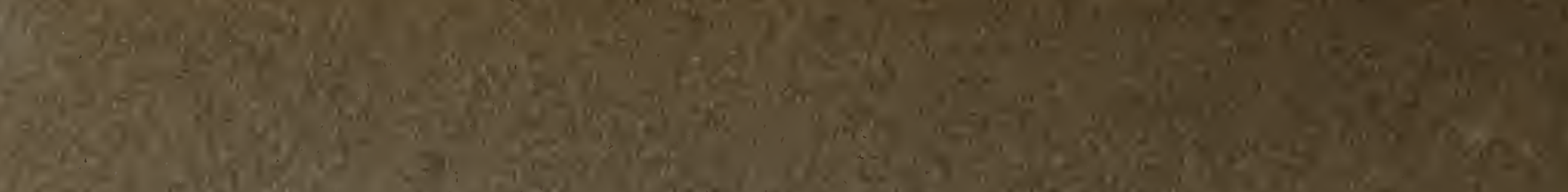

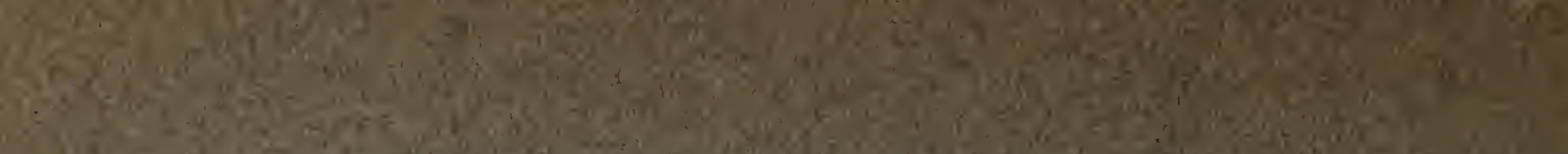

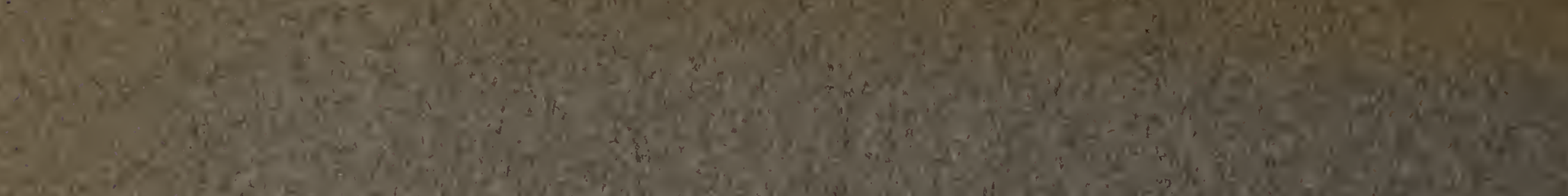

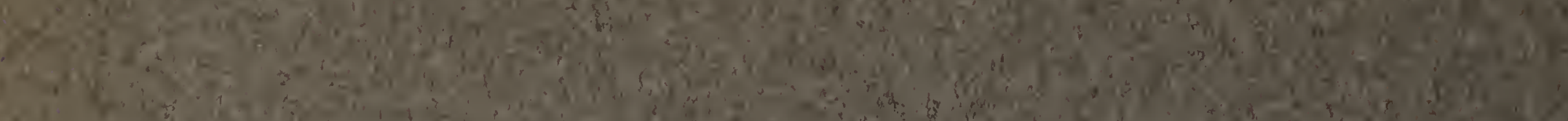
(3)

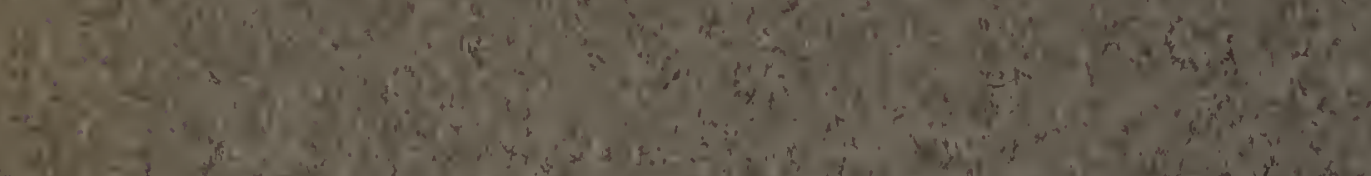
(4) (4)

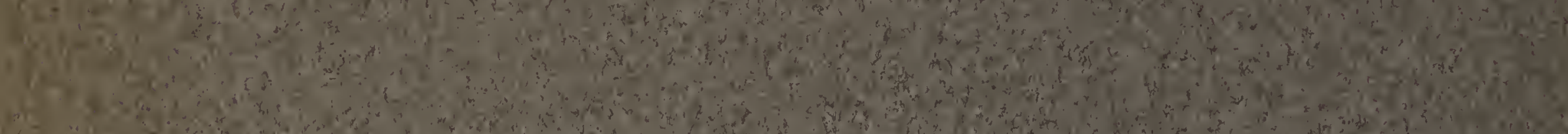

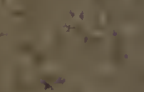
Whe 1020

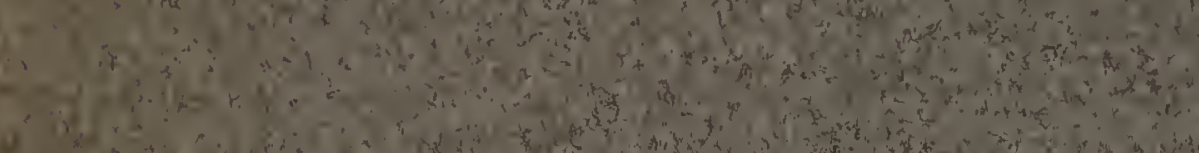

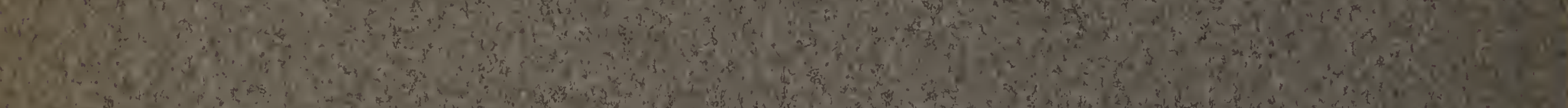

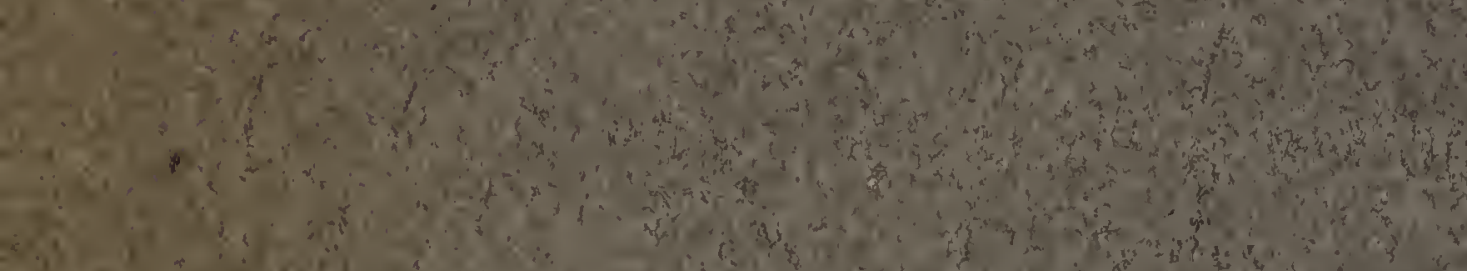

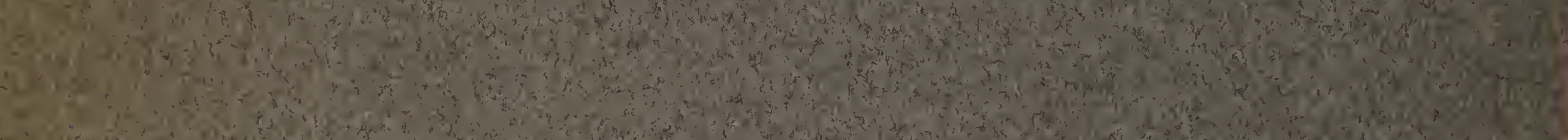

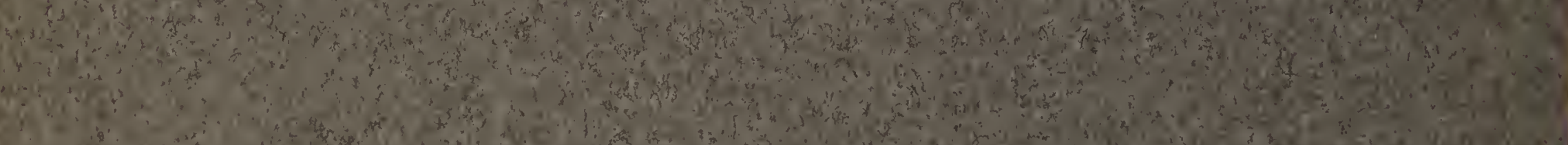

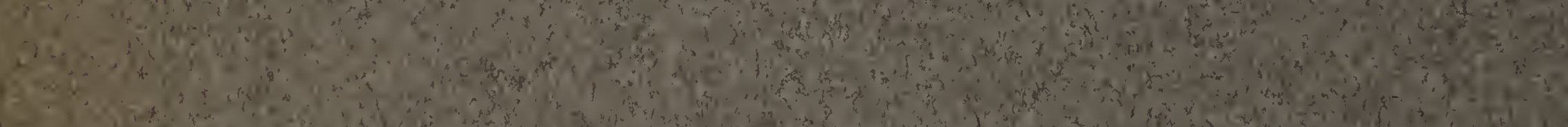

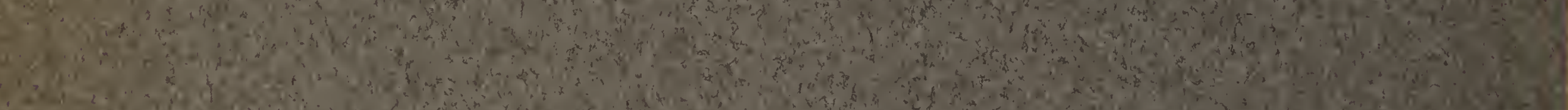

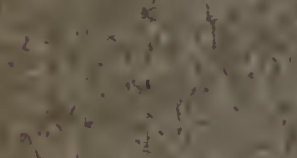

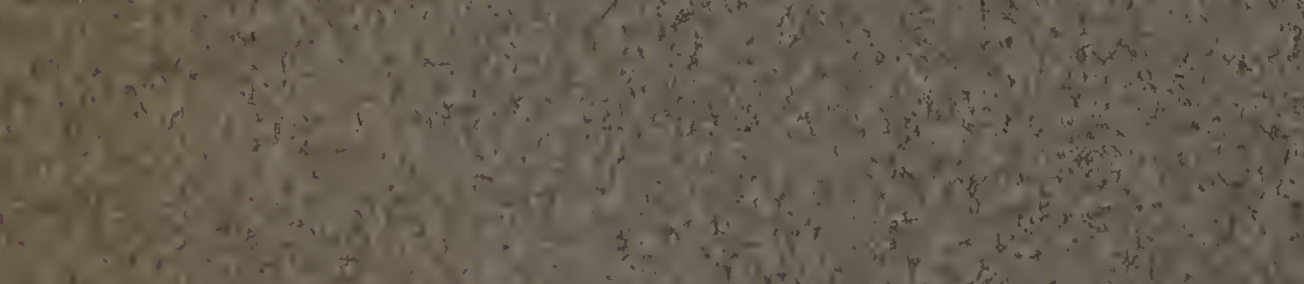

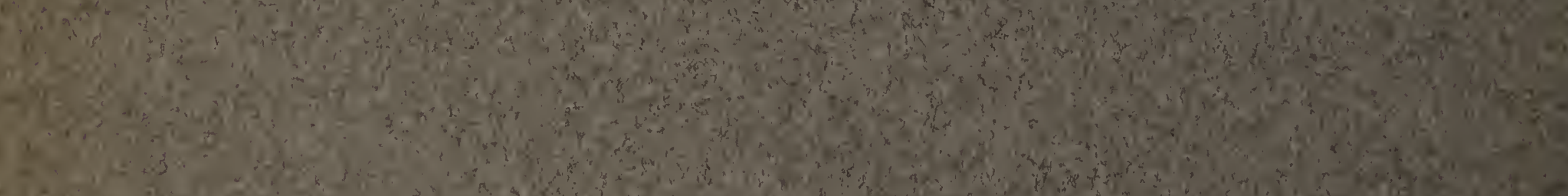
(14.

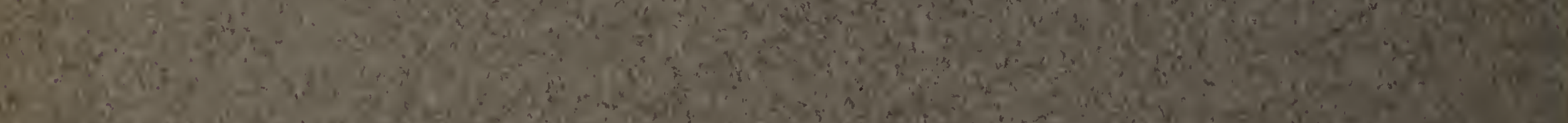

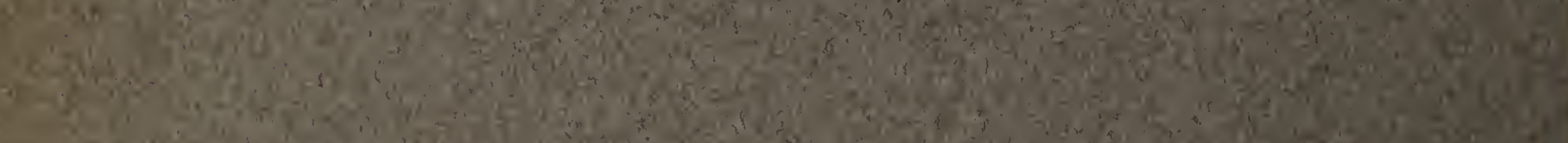

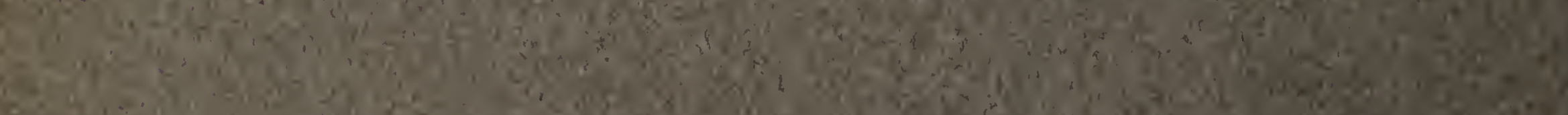

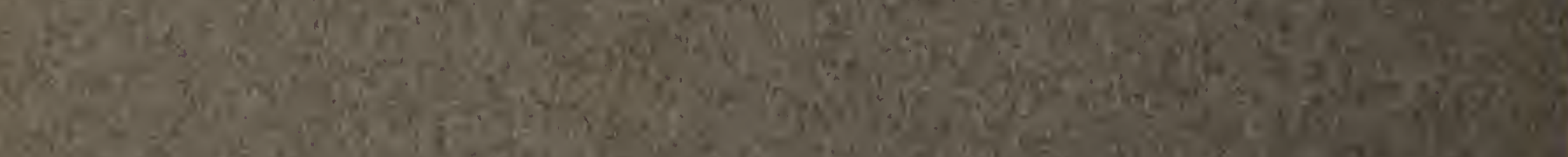

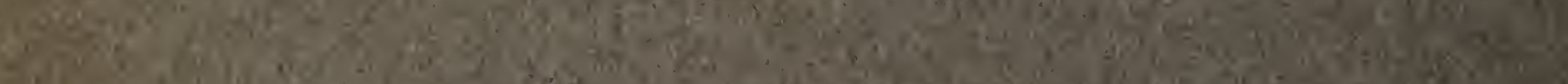

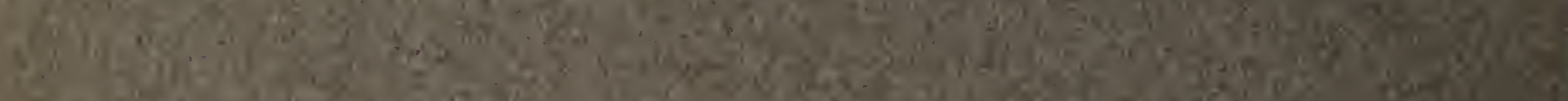
Whi the

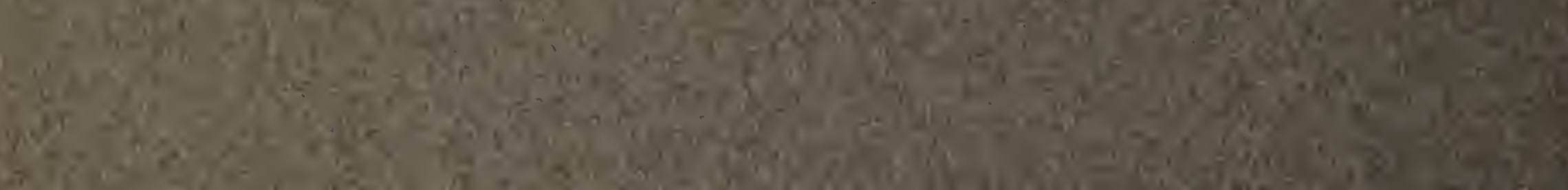

